NASA/TM-2004-213220

Neptune Orbiters Utilizing Solar and Radioisotope Electric Propulsion

Douglas I. Fiehler

QSS Group, Inc., Cleveland, Ohio

Steven R. Oleson

Glenn Research Center, Cleveland, Ohio 
Since its founding, NASA has been dedicated to the advancement of aeronautics and space science. The NASA Scientific and Technical Information (STI) Program Office plays a key part in helping NASA maintain this important role.

The NASA STI Program Office is operated by Langley Research Center, the Lead Center for NASA's scientific and technical information. The NASA STI Program Office provides access to the NASA STI Database, the largest collection of aeronautical and space science STI in the world. The Program Office is also NASA's institutional mechanism for disseminating the results of its research and development activities. These results are published by NASA in the NASA STI Report Series, which includes the following report types:

- $\quad$ TECHNICAL PUBLICATION. Reports of completed research or a major significant phase of research that present the results of NASA programs and include extensive data or theoretical analysis. Includes compilations of significant scientific and technical data and information deemed to be of continuing reference value. NASA's counterpart of peerreviewed formal professional papers but has less stringent limitations on manuscript length and extent of graphic presentations.

- TECHNICAL MEMORANDUM. Scientific and technical findings that are preliminary or of specialized interest, e.g., quick release reports, working papers, and bibliographies that contain minimal annotation. Does not contain extensive analysis.

- CONTRACTOR REPORT. Scientific and technical findings by NASA-sponsored contractors and grantees.
- CONFERENCE PUBLICATION. Collected papers from scientific and technical conferences, symposia, seminars, or other meetings sponsored or cosponsored by NASA.

- SPECIAL PUBLICATION. Scientific, technical, or historical information from NASA programs, projects, and missions, often concerned with subjects having substantial public interest.

- TECHNICAL TRANSLATION. Englishlanguage translations of foreign scientific and technical material pertinent to NASA's mission.

Specialized services that complement the STI Program Office's diverse offerings include creating custom thesauri, building customized databases, organizing and publishing research results ... even providing videos.

For more information about the NASA STI Program Office, see the following:

- Access the NASA STI Program Home Page at http://www.sti.nasa.gov

- E-mail your question via the Internet to help@sti.nasa.gov

- Fax your question to the NASA Access Help Desk at 301-621-0134

- Telephone the NASA Access Help Desk at 301-621-0390

- Write to:

NASA Access Help Desk

NASA Center for AeroSpace Information 7121 Standard Drive

Hanover, MD 21076 
NASA/TM-2004-213220

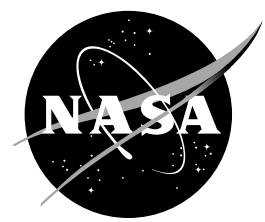

\section{Neptune Orbiters Utilizing Solar and Radioisotope Electric Propulsion}

Douglas I. Fiehler

QSS Group, Inc., Cleveland, Ohio

Steven R. Oleson

Glenn Research Center, Cleveland, Ohio

Prepared for the

40th Joint Propulsion Conference and Exhibit

cosponsored by the AIAA, ASME, SAE, and ASEE

Fort Lauderdale, Florida, July 11-14, 2004

National Aeronautics and

Space Administration

Glenn Research Center 


\section{Acknowledgments}

NASA's Project Prometheus supported the work described within this paper, in whole or part, as part of the program's technology development and evaluation activities. Any opinions expressed are those of the authors and do not necessarily reflect the views of Project Prometheus.

Trade names or manufacturers' names are used in this report for identification only. This usage does not constitute an official endorsement, either expressed or implied, by the National Aeronautics and Space Administration.

Available from

NASA Center for Aerospace Information 7121 Standard Drive

Hanover, MD 21076
National Technical Information Service 5285 Port Royal Road Springfield, VA 22100 


\title{
Neptune Orbiters Utilizing Solar and Radioisotope Electric Propulsion
}

\author{
Douglas I. Fiehler \\ QSS Group, Inc. \\ Cleveland, Ohio 44135 \\ Steven R. Oleson \\ National Aeronautics and Space Administration \\ Glenn Research Center \\ Cleveland, Ohio 44135
}

In certain cases, Radioisotope Electric Propulsion (REP), used in conjunction with other propulsion systems, could be used to reduce the trip times for outer planetary orbiter spacecraft. It also has the potential to improve the maneuverability and power capabilities of the spacecraft when the target body is reached as compared with nonelectric propulsion spacecraft. Current missions under study baseline aerocapture systems to capture into a science orbit after a Solar Electric Propulsion (SEP) stage is jettisoned. Other options under study would use all REP transfers with small payloads. Compared to the SEP stage/Aerocapture scenario, adding REP to the science spacecraft as well as a chemical capture system can replace the aerocapture system but with a trip time penalty. Eliminating both the SEP stage and the aerocapture system and utilizing a slightly larger launch vehicle, Star 48 upper stage, and a combined REP/Chemical capture system, the trip time can nearly be matched while providing over a kilowatt of science power reused from the REP maneuver. A Neptune Orbiter mission is examined utilizing single propulsion systems and combinations of SEP, REP, and chemical systems to compare concepts.

\section{Introduction}

Various authors have studied the use of electric propulsion powered by radioisotope power sources for science missions beyond earth orbit. ${ }^{1-5}$ More recent work has shown that such radioisotope electric propulsion (REP) spacecraft can orbit or co-orbit various large and small science targets beyond Mars with transit times comparable to large fission-based nuclear electric propulsion (NEP) vehicles, but deliver less science payload with proportionately less power available for science instruments. Although REP vehicles would be much smaller and have less on-board power available for science instruments than fission-based NEP, REP vehicles, like those using NEP, could conduct missions that are not accessible to chemical, solar electric or aerocapture vehicles. ${ }^{6}$ This recent work discovered that using a medium class launch vehicle with an upper stage can reduce the REP trip times $50 \%$ from past estimates by using the launch vehicle to provide the Earth escape and acceleration while the REP (generally) only has to decelerate and shape the trajectory to capture at the target.

A Neptune Orbiter mission has been identified as a mission of much interest, ${ }^{7}$ and the performance of many spacecraft configurations have been analyzed in reference to this mission. The NASA's Evolutionary Xenon Thruster (NEXT) Program used a Neptune Orbiter mission as one of its deep space design reference missions to help in the development of requirements for the system. ${ }^{8}$ Many propulsion systems were traded against each other using this Neptune mission during the Integrated In-Space Transportation Planning studies. ${ }^{9}$ These systems included chemical, SEP, NEP, solar and nuclear-thermal propulsion, solar sails, and tethers. An all-solar powered mission, utilizing power antenna technology, was also studied. ${ }^{10}$

The Vision for Space Exploration" calls for "robotic explorers [to] visit new worlds first, to obtain scientific data, assess risks to our astronauts, demonstrate breakthrough technologies, identify space resources, and send tantalizing imagery back to Earth." Advanced solar and radioisotope power, electric propulsion, and chemical propulsion as well as aerocapture are technologies that can enable many of these goals set forth in "The Vision." 
The combination of these technologies has the potential to offer many benefits to the robotic explorers of the next decades. These technologies can also be applied, once demonstrated, to the human exploration missions to the Moon, Mars, and beyond that will follow these robotic explorers.

\section{Systems Analyses}

\section{A. Spacecraft Analysis}

A combination of propulsion systems make up the different spacecraft configurations examined in this study. These spacecraft configurations are detailed in Table 1, and include REP, SEP, and chemical propulsion systems individually and combined, as well as aerocapture. Depending upon the combination of propulsion options the science spacecraft will require a different design. Stage and Spacecraft designs originate from spacecraft concept studies conducted both at Glenn Research Center and at the Jet Propulsion Laboratory.

\section{Table 1: Spacecraft Configurations}

\begin{tabular}{|l|l|}
\hline SEP-Aerocapture & Baseline case from the NEXT design reference missions. \\
\hline REP & Based on the NASA GRC REP concept study. \\
\hline SEP-REP & Combination of SEP stage and REP spacecraft, using REP to capture at Neptune. \\
\hline SEP-Chem & Combination of SEP stage and a chemical stage to capture at Neptune. \\
\hline SEP-REP-Chem & Combination of SEP stage, REP spacecraft, and chemical stage for Neptune capture. \\
\hline Chemical & Spacecraft utilizing only chemical propulsion to deliver the spacecraft. \\
\hline
\end{tabular}

\section{Radioisotope Electric Propulsion Spacecraft}

The baseline REP spacecraft was developed as part of an REP concept study led by the Advanced Concepts Branch at NASA GRC. This concept (see Fig. 1) included all necessary components to successfully accomplish a New Frontiers class mission to the Trojan Asteroids at the Jupiter L4 point. The craft includes an advanced radioisotope power system (ARPS), an ion thruster system for primary propulsion, pulsed plasma thruster (PPT) system for attitude control, communications system, and small $(20-50 \mathrm{~kg})$ science payload. The design uses a truss structure to help minimize the mass of the spacecraft. The spacecraft mass equipment list is shown in Table 3 .

The ARPS in its baseline configuration provides 750 We of power for propulsion and approximately $60 \mathrm{We}$ for housekeeping functions. However, the full $810 \mathrm{We}$ of power is available for housekeeping, science, and communications during non-thrusting periods of the

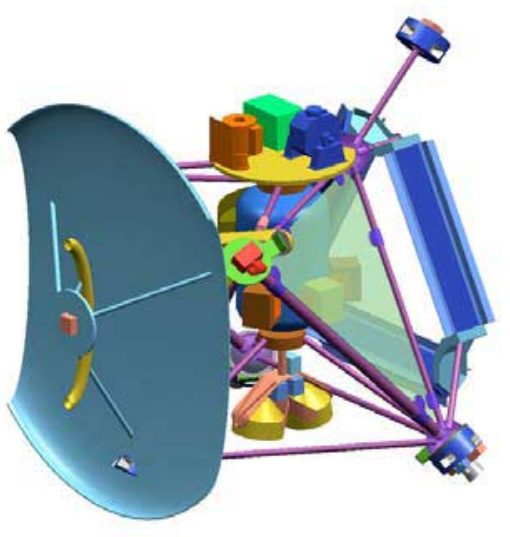
mission. The ARPS system is assumed to have a specific power of $8 \mathrm{We} / \mathrm{kg}^{12}$ in order to scale the spacecraft to higher power levels for this study, and the structure is scaled as $14 \%$ of the total spacecraft dry mass. Table 2 illustrates the scaling of the REP spacecraft from $0.81 \mathrm{kWe}$ to $3.06 \mathrm{kWe}$.

Table 2: Scaling of the REP Spacecraft with Increasing Power (Masses include approximately 30\% Contingency).

\begin{tabular}{rcccccc} 
Spacecraft Power & $0.81 \mathrm{kWe}$ & $1.06 \mathrm{kWe}$ & $1.56 \mathrm{kWe}$ & $2.06 \mathrm{kWe}$ & $2.56 \mathrm{kWe}$ & $3.06 \mathrm{kWe}$ \\
\hline Science & $48 \mathrm{~kg}$ & $48 \mathrm{~kg}$ & $48 \mathrm{~kg}$ & $48 \mathrm{~kg}$ & $48 \mathrm{~kg}$ & $48 \mathrm{~kg}$ \\
ACS & $46 \mathrm{~kg}$ & $46 \mathrm{~kg}$ & $46 \mathrm{~kg}$ & $46 \mathrm{~kg}$ & $46 \mathrm{~kg}$ & $46 \mathrm{~kg}$ \\
Comm. \& C\&DH & $71 \mathrm{~kg}$ & $71 \mathrm{~kg}$ & $71 \mathrm{~kg}$ & $71 \mathrm{~kg}$ & $71 \mathrm{~kg}$ & $71 \mathrm{~kg}$ \\
Structures & $66 \mathrm{~kg}$ & $71 \mathrm{~kg}$ & $81 \mathrm{~kg}$ & $91 \mathrm{~kg}$ & $101 \mathrm{~kg}$ & $112 \mathrm{~kg}$ \\
Thermal & $25 \mathrm{~kg}$ & $25 \mathrm{~kg}$ & $25 \mathrm{~kg}$ & $25 \mathrm{~kg}$ & $25 \mathrm{~kg}$ & $25 \mathrm{~kg}$ \\
Power \& Propulsion & $216 \mathrm{~kg}$ & $247 \mathrm{~kg}$ & $309 \mathrm{~kg}$ & $371 \mathrm{~kg}$ & $433 \mathrm{~kg}$ & $495 \mathrm{~kg}$ \\
\hline & $472 \mathrm{~kg}$ & $508 \mathrm{~kg}$ & $580 \mathrm{~kg}$ & $652 \mathrm{~kg}$ & $724 \mathrm{~kg}$ & $797 \mathrm{~kg}$
\end{tabular}


Table 3: REP Concept Study Mass Equipment List

\begin{tabular}{|c|c|c|c|c|c|}
\hline $\begin{array}{l}\text { REP OPTO } \\
\text { Item }\end{array}$ & Qty & Comments & $\begin{array}{l}\text { Est. Unit } \\
\text { Mass, kg }\end{array}$ & $\begin{array}{l}\text { Conting } \\
\text { ency, } \\
\%\end{array}$ & $\begin{array}{l}\text { Total Est } \\
\text { Mass, kg }\end{array}$ \\
\hline \multicolumn{5}{|c|}{ Bus Science \& non power/propulsion } & 258.1 \\
\hline \multicolumn{4}{|l|}{ Science } & & 48.1 \\
\hline MDIS & & | Mercury dual imaging system & 6.8 & 30 & 8.8 \\
\hline MASCS & 1 & Surface Comp Spectrometer & 3.1 & 5 & 3.3 \\
\hline DPU & 2 & Data Prcoessing Units & 3.3 & 5 & 6.9 \\
\hline Misc. & 1 & Harness, etc & 6.8 & 30 & 8.8 \\
\hline GRNS & 1 & Gamma-ray \& neutron spectrometer & 13.4 & 10 & 14.7 \\
\hline Mapping Optics & 1 & $\begin{array}{l}\text { Added Item to account for Special Optics } \\
\text { needed for mapping. Work with MDIS. }\end{array}$ & 2 & 30 & 2.6 \\
\hline EPPS & & $\begin{array}{l}\text { Energetic particle and plasma } \\
\text { spectrometer }\end{array}$ & 2.6 & 10 & 2.86 \\
\hline \multicolumn{4}{|c|}{ Attitude Control System } & & 46.3 \\
\hline Star Tracker & 3 & Mini star tracker & 0.3 & 30 & 1.2 \\
\hline PPT & 4 & $\begin{array}{l}\text { Mass estimate based on advanced PPT } \\
\text { components developed under contract } \\
\text { with Unison Industries. }\end{array}$ & 5 & 30 & 26.0 \\
\hline PPU-ACS & 1 & $\begin{array}{l}\text { Power Conditioning and controls for } \\
\text { PPTs }\end{array}$ & 2.5 & 30 & 3.3 \\
\hline $\begin{array}{l}\text { Inter stellar } \\
\text { compas }\end{array}$ & 2 & & 2.9 & 30 & 7.5 \\
\hline $\begin{array}{l}\text { Attitude } \\
\text { Processing } \\
\text { Electronics }\end{array}$ & 2 & $\begin{array}{l}2 \text { sets, TBD (Estimate is under } 4 \mathrm{~kg} \\
\text { each, and under } 5 \text { Watts) }\end{array}$ & 3 & 30 & 7.8 \\
\hline $\begin{array}{l}\text { Passive sun } \\
\text { sensor }\end{array}$ & 4 & & 0.1 & 30 & 0.5 \\
\hline \multicolumn{4}{|c|}{ Communications etc. } & & 71.3 \\
\hline $\begin{array}{l}\text { S/C Main } \\
\text { Computer }\end{array}$ & 2 & S603 Rad Hard version & 5.5 & 30 & 14.3 \\
\hline $\begin{array}{l}\text { High Gain } \\
\text { Antenna }\end{array}$ & 1 & 2.1-m high gain antenna (New Horizon) & 9.47 & 30 & 12.3 \\
\hline $\begin{array}{l}\text { Low Gain } \\
\text { Antenna }\end{array}$ & 3 & X-band quadrifilar & 0.16 & 30 & 0.624 \\
\hline $\begin{array}{l}\text { Low Noise Amp } \\
\text { (LNA) }\end{array}$ & 3 & & 0.01 & 30 & 0.039 \\
\hline USO 2030 & 2 & Ultra Stable Oscillators & 0.55 & 30 & 1.43 \\
\hline X-band SSA & 2 & Solid State Amp & 1.1 & 30 & 2.86 \\
\hline TWTA & 1 & Ka Band & 2.2 & 30 & 2.86 \\
\hline
\end{tabular}
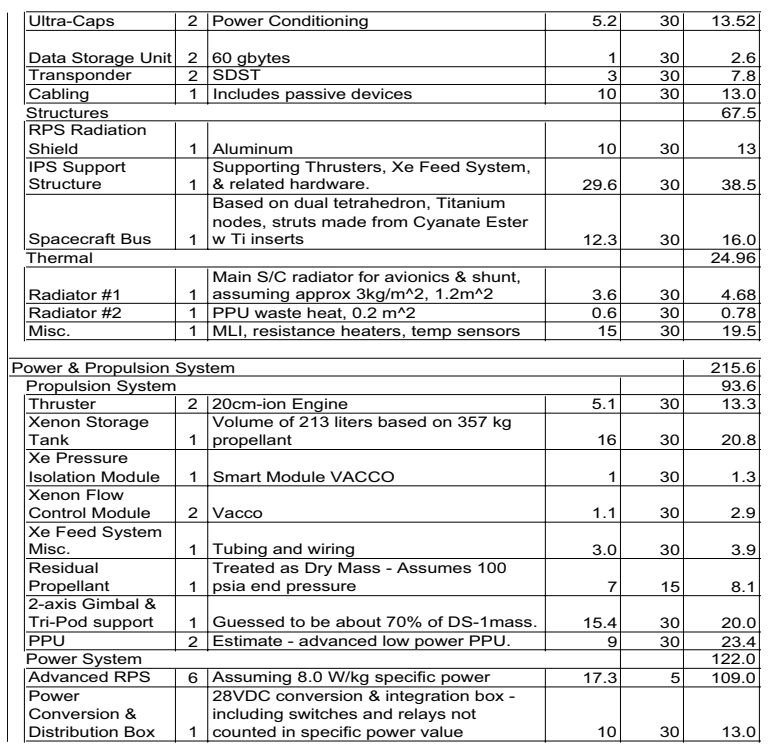

\begin{tabular}{|l|l|l}
$\begin{array}{l}\text { Conversion \& } \\
\text { Distribution Box }\end{array}$ & 1 & $\begin{array}{l}\text { including switches and relays no } \\
\text { counted in specific power value }\end{array}$ \\
\hline
\end{tabular}

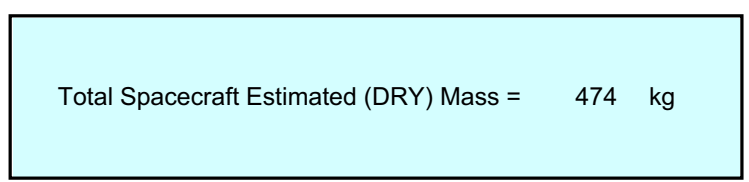

The ion propulsion system includes a mix of existing and in-development hardware designs. The two thrusters included in this configuration are $20 \mathrm{~cm}$ diameter thrusters, which currently exist only as a lab model design at NASA GRC. The two power processing units (PPUs) and the digital control and interface unit (DCIU) are based on the design of the NEXT PPU and DCIU. The ion thruster xenon feed system is a design developed by VACCO under a contract from NASA. A composite over-wrapped tank with a titanium liner and capacity of approximately $350 \mathrm{~kg}$ of xenon completes the electric propulsion system. $\mathrm{I}_{\mathrm{SP}} \mathrm{S}$ for the ion system are 3000 to $5000 \mathrm{~s}$ and were optimized for the analyses in this paper.

The PPT system is needed to provide attitude control for the spacecraft over long periods of time. The Teflon ${ }^{\circledR}$ fueled PPTs and their PPU are based on components developed under a NASA contract with Unison Industries that are presently undergoing life evaluation at NASA Glenn. ${ }^{13}$ The PPTs provide roll-control during periods of ion engine thrusting and three-axis control during coast and science periods.

The communications system is mostly composed of components that are fully developed or will be by the time they are needed for a flight program. These include a $2.1 \mathrm{~m}$ high-gain antenna under development for the New Horizons mission to Pluto and the Kuiper Belt, a low-gain antenna, Ka-band traveling wave tube, and X-band solidstate amplifier among other pertinent communications equipment.

The science package chosen for the REP concept study includes instruments important for studies of the Trojan Asteroids, but can be modified within the same range of mass and power for other interplanetary science missions. The instruments included in the REP concept study are the Mercury Dual Imaging System, Surface Composition Spectrometer, Gamma Ray and Neutron Spectrometer, and an Energetic Particle and Plasma Spectrometer.

For this study the REP propulsion system is assumed integrated with the Neptune science spacecraft. Two options are explored; REP only for capture via a spiral-in and REP combined with a chemical system to capture at Neptune.

\section{Solar Electric Propulsion Stage}

The SEP stage design is the design conceived for the NEXT Team-X study completed in October $2003^{14}$ (see Fig. 2). It consists of a large solar array system that powers a NEXT ion propulsion system. It also includes the required structure and thermal control. The SEP stage does not include avionics or attitude control hardware, as these functions are to be controlled by the attached orbiter. The total dry mass of the baseline SEP module is 
approximately $1200 \mathrm{~kg}$. The SEP module is jettisoned at a distance of approximately 3 AU where the solar flux is insufficient to provide power for the NEXT thrusters.

A maximum of $30 \mathrm{kWe}$ is provided to the SEP stage in its baseline configuration. Two solar array wings carrying three circular Ultraflex solar arrays each provide the power. Each array is approximately 5 $\mathrm{m}$ in diameter.

The NEXT ion propulsion system consists of the hardware developed under the NEXT project. The thruster is a $40 \mathrm{~cm}$ beam diameter ion thruster that operates at up to $7 \mathrm{kWe}$ of input power. ${ }^{15}$ The NEXT program is also developing the $\mathrm{PPU}^{16}$ and xenon propellant management system ${ }^{17}$ designs. The tank is assumed to be a single ultralight composite tank kept

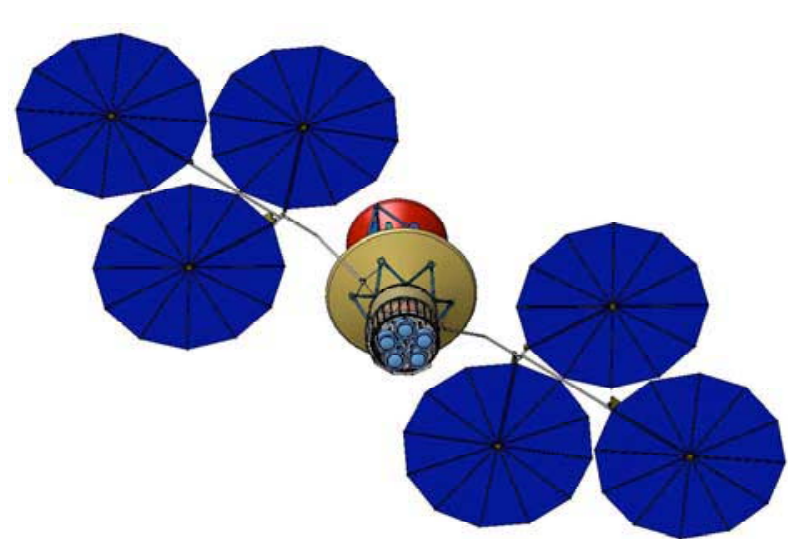

Figure 2: SEP Module Conceptual Design cold by layers of thermal multi-layer insulation. The baseline SEP stage configuration includes up to four operating thrusters and PPUs and one spare of each for a total of five thrusters and PPUs. The thrusters are switched on and off as solar array power changes with distance to the Sun.

The science orbiter propelled by the SEP stage consists of several options for this study. The non-REP science orbiters include a $500 \mathrm{~kg}$ bus and science mass including $200 \mathrm{~W}$ of power. ${ }^{18}$ This was the mass assumed in the previous SEP-aerocapture studies and is assumed to include all science, power, propulsion, communications, avionics, etc. needed for an extended science mission in orbit of Neptune with flybys of Triton. In addition this 500 $\mathrm{kg}$ orbiter must provide attitude control for the combined SEP/orbiter (approximate total of $3000 \mathrm{~kg}$ ), a separation system, and thermal system for the extremes of Venus to Neptune. In addition to the $500 \mathrm{~kg}$ orbiter an additional aerocapture system (approximately $250 \mathrm{~kg}$ ) as well as a chemical system (approximately $100 \mathrm{~kg}$ ) to raise the periapsis of the aerocapture orbit out of the Neptune upper atmosphere is required. No breakdowns for this $500 \mathrm{~kg}$ orbiter mass were available (except an approximate $50 \mathrm{~kg}$ science mass) from the SEP-aerocapture studies. It is assumed that the design uses similar technologies and margins to the REP design to make the two orbiters comparable in required function. (Further studies are warranted to break out all of the various different function depending upon scenario and assess the mass impacts.) For the All Chemical, REP, and REP/Chemical options the science orbiter will have the appropriate propulsion system(s) integrated with the spacecraft.

\section{Configurations Utilizing a Chemical Capture System}

Several configurations utilize a chemical propulsion stage to capture into Neptune orbit. This system is assumed to be an advanced pressure-fed, Earth storable bipropellant chemical propulsion stage with an $\mathrm{I}_{\mathrm{SP}}$ of $328 \mathrm{~s} .{ }^{19}$ The dry mass of the chemical system is assumed to be $11 \%$ of the mass of propellant required. ${ }^{19}$

\section{B. Launch Vehicle}

Two launch vehicles are examined as part of this study. When comparing the performance of different spacecraft (i.e. REP vs. SEP-REP), a Delta IV M+ $(4,2)$ is used. This Delta IV launch vehicle was chosen because of its use in the NEXT design reference mission studies. A secondary part of this study was performed to see the benefit of changing launch vehicles to an Atlas V 551. This launch vehicle was chosen because of its use as the baseline launch vehicle in the aforementioned REP concept study. Similar performance to the Atlas V 551 could be achieved using a Delta IV M+ $(5,4)$. For

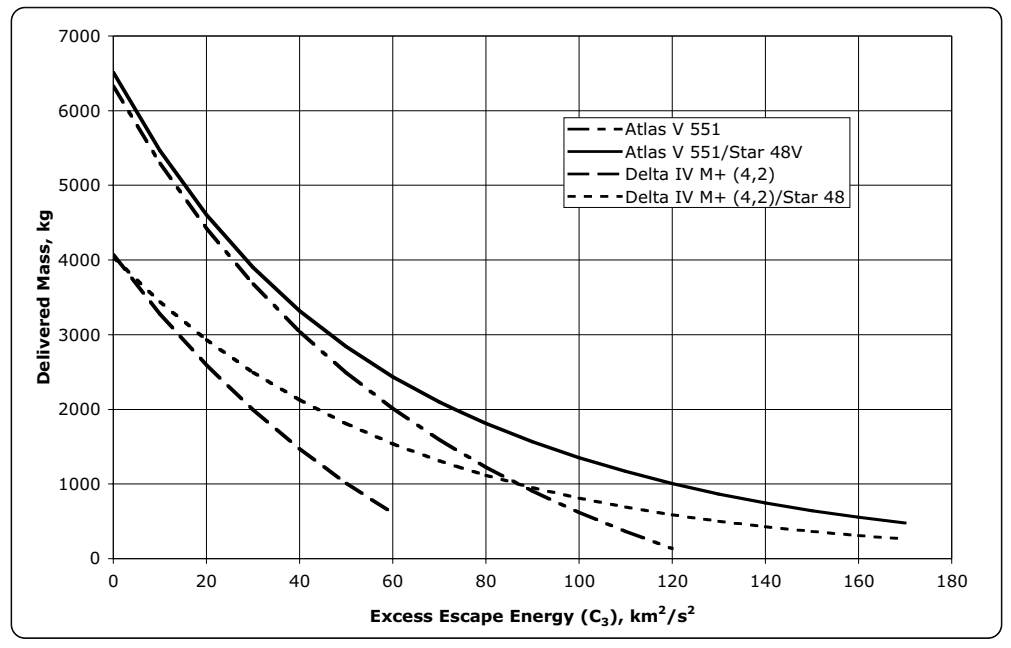

Figure 3: Atlas V 551 and Delta IV M+ $(4,2)$ Launch Vehicle Performance with and without the Star 48 Motor $^{20-23}$ 
configurations not using the SEP stage, a high excess escape energy $\left(\mathrm{C}_{3}\right)$ launch was performed with a Star 48 motor topping the Delta and Atlas launch vehicles. Such high-energy escapes are needed for REP related mission scenarios not using SEP. The performance of these vehicles with and without the Star 48 motor can be seen in Fig. 3.

\section{Mission Analyses}

\section{A. Mission Descriptions}

Two general mission profiles are used for this study, SEP stage injection and high-energy launch vehicle injection. The SEP stage injection launches approximately $3000 \mathrm{~kg}$ to a departure $C_{3}$ of approximately $10 \mathrm{~km}^{2} / \mathrm{s}^{2}$. It then performs a Venus flyby to increase the spacecraft's velocity and propel it to the Neptune encounter (see Fig 4). The high-energy launch scenario launches from 450 to $700 \mathrm{~kg}$ to departure $\mathrm{C}_{3} \mathrm{~s}$ of 140 to $75 \mathrm{~km}^{2} / \mathrm{s}^{2}$. The high-energy launch provides most of the energy needed to reach Neptune ${ }^{24}$ (see Fig. 5).

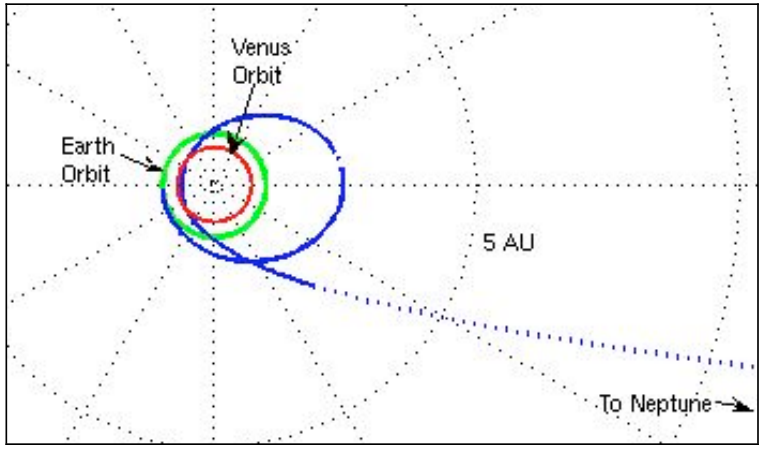

Figure 4: SEP Trajectory

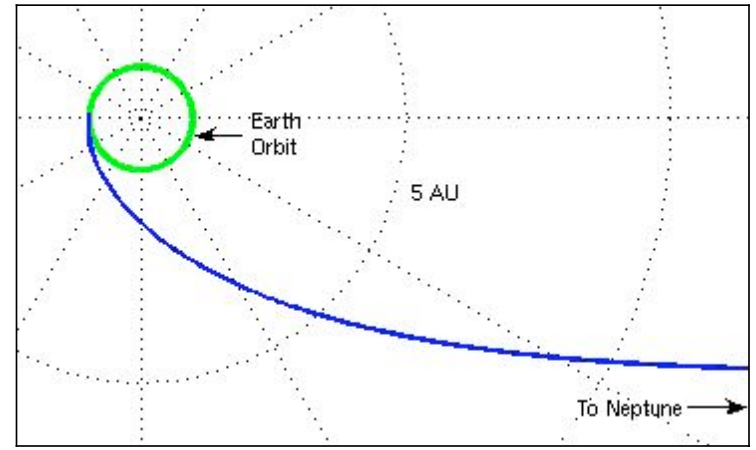

Figure 5: REP Trajectory

Two different final orbits are attained at Neptune, depending on the capture technique. Aerocapture, chemical, and combined REP/Chemical capture attain a highly elliptic orbit around Neptune with periodic flybys of Neptune's moon, Triton. This orbit is $6191 \mathrm{~km}$ by $330,000 \mathrm{~km}$ altitude. REP capture without chemical propulsion utilizes the electric propulsion system to spiral to the same orbit as Triton and then into a Triton orbit as the final science orbit.

\section{B. Trajectory Optimization and Analysis}

Trajectory design and optimization was completed using the Direct Trajectory Optimization Method (DTOM) code. As the name suggests, the DTOM is a direct method for obtaining optimal, low-thrust, interplanetary trajectories. ${ }^{25}$ The DTOM numerically integrates the three-dimensional equations of motion using modified equinoctial orbital elements to accommodate circular orbits (eccentricity of 0 ). ${ }^{26}$ The parameterized continuous-time control, thrust and coast lengths, launch date scaling factor, and Earth-escape parameters define the generic design space. More specialized problems can be defined with planetary gravity assists, loiter periods at the target body (used for sample-return missions), optimization of power level and specific impulse (either single value or parameterized continuous-time profile), and specialized thruster system models. Previous REP trajectories have been verified with the more widely used VARITOP trajectory optimization code. ${ }^{27}$

The total trip times of the different configurations were used for comparison. In the cases where an REP spacecraft was part of the configuration, the power level into the PPUs was varied between $0.75 \mathrm{kWe}$ and $3.0 \mathrm{kWe}$, and the appropriate dry mass was added, to complete the trade of trip time versus REP spacecraft power. REP spacecraft power, in this case, is defined as the power into the PPUs plus $60 \mathrm{We}$ of housekeeping power available for spacecraft operation during ion thruster cruise. The baseline case used for comparison was the SEP-Aerocapture case with a trip time of approximately 10.5 years to a final Neptune orbit. This baseline case delivers a spacecraft with a mass of approximately $500 \mathrm{~kg}$ as described in the spacecraft analysis section.

\section{Performance of the Various Spacecraft Configurations}

Trip times of the previously described spacecraft configurations ranged from 10 to 20 years when launched on a Delta IV M+ $(4,2)$ (see Fig. 6). The SEP-Aerocapture configuration achieved the minimum time to Neptune orbit of 10.4 years, and the REP took the longest time. However, the worst performing configuration was the direct allchemical spacecraft with a trip time of 12 years, this all-chemical configuration could only deliver an insufficient 80 $\mathrm{kg}$ spacecraft to Neptune. The REP-Chem, SEP-Chem, and SEP-REP-Chem configurations delivered their 
respective spacecraft to Neptune orbit in between 12 and 15 years, whereas the SEP-REP configuration required between 14 and 18 years.

The REP configurations employing the chemical capture stage were relatively stable with changing spacecraft power levels as compared to those using REP as the capture means. The trip times decreased by approximately one year for the chemical capture cases and approximately 4 years for the REP capture cases with an increase of 1.5 $\mathrm{kWe}$. However, the trip time curves flatten out dramatically above 1.5 $\mathrm{kWe}$, diminishing the trip time savings associated with higher spacecraft power.

Examining the spacecraft configurations' mass breakdowns (see Fig. 7), conclusions can be drawn about the performance shown in Fig. 6. Usage of the launch vehicle is determined by the existence of the SEP stage. Configurations with the SEP stage launch to a low departure $\mathrm{C}_{3}$, approximately 10 $\mathrm{km}^{2} / \mathrm{s}^{2}$, to accommodate the high mass of the configuration whereas those without launch to a high departure $\mathrm{C}_{3}$, approximately $80-140 \mathrm{~km}^{2} / \mathrm{s}^{2}$, to accommodate their much lower mass. That is, the SEP stage provides much of the energy, in conjunction with a Venus flyby, needed to reach Neptune, whereas the configurations without the SEP stage utilize the launch vehicle to provide most of the energy needed to reach Neptune without a Venus flyby. A second conclusion that the mass breakdown makes apparent is the relative performance of capturing using a chemical propulsion system versus the electric propulsion system. The total masses of the REP and REP-Chem and the SEP-REP and SEP-REP-Chem are very close, however the trip times of the configurations using a chemical propulsion system to capture are more than 2 years shorter. Up until the capture, the performance of these systems is fairly equal, but because of the different means of capture, the capture time is dramatically different. A chemical propulsion system can complete the capture maneuver and deliver the spacecraft to its final orbit in a matter of hours, whereas the electric propulsion system takes months or years to deliver the spacecraft. The relative scientific value of the different orbits - flybys of Triton using a chemical capture versus orbiting Triton need to be assessed.

The arrival $\mathrm{C}_{3}$ (see Fig. 7) also helps to explain the performance of these configurations. The high arrival $\mathrm{C}_{3}$ of the SEP-Aerocapture configuration and its low mass compared to other SEP configurations is the reason for the short comparative trip time to Neptune. The Chem and SEP-Chem configurations cannot accommodate as high of an arrival $\mathrm{C}_{3}$ because of the low $\mathrm{I}_{\mathrm{SP}}$ of the chemical system and therefore the amount of propellant required for capture at Neptune. Comparing REP versus REP-Chem and SEP-REP versus SEP-REP-Chem, one can see that the shortened trip time of the chemical capture configurations results in non-zero arrival $\mathrm{C}_{3} \mathrm{~S}$. Thus in these chemical capture configurations, the REP system is not required to remove as much energy from the spacecraft trajectory in 
favor of the chemical system performing a short capture burn near Neptune to remove the energy. The capture is performed more efficiently and quicker near Neptune as opposed to more than a year of spiraling with the ion thrusters to reach the final science orbit.

The $\mathrm{I}_{\mathrm{SP}}$ of the REP ion system was optimized by DTOM in each of the analyses. Total propulsion system performance (efficiency) was varied based on required $I_{\mathrm{sp}}$ by the function: Efficiency $=\left(\mathrm{bb} * \mathrm{I}_{\mathrm{sp}}{ }^{2}\right) /\left(\mathrm{I}_{\mathrm{sp}}{ }^{2}+\mathrm{dd}^{2}\right)$ where $\mathrm{bb}=0.8358$ and $\mathrm{dd}=2152.99$ seconds. This trend is representative of sub-kilowatt thruster test data at similar power levels. ${ }^{28-31}$ Optimal REP ion thruster $\mathrm{I}_{\mathrm{SP}} \mathrm{S}$ for the REP and REPChem spacecraft are between 4000 and $5500 \mathrm{~s}$ whereas the REP ion thruster optimal $\mathrm{I}_{\mathrm{SP}} \mathrm{S}$ for the SEP-REP and SEP-REP-Chem configurations are between 2800 and $4500 \mathrm{~s}$ (see Fig. 8), and in each case increase with spacecraft power level. $\mathrm{I}_{\mathrm{SP}} \mathrm{S}$ are higher for the non-SEP configurations, because the REP ion thrusters are performing more of the total mission $\Delta \mathrm{v}$ than in the configurations with SEP, thus more efficient use of the propellant is required. The constrained launch mass of the high departure $\mathrm{C}_{3}$ non-SEP configurations also demands more efficient use of the onboard propellant.

\section{Launch Vehicle Performance}

Increasing the launch vehicle size from a Delta IV M+ (4,2) to an Atlas V 551 has trip time benefits for each of the configurations examined (see Fig. 9). Trip times decreased for non-SEP configurations by approximately three years, irrespective of the spacecraft power level. The SEP-Aerocapture trip time only decreased by 1.5 months due to the number of constraints on that trajectory (i.e. Venus flyby and maximum aerocapture velocity), which is the case for the other SEP configurations, also. Changing launch vehicles from the Delta IV M+ $(4,2)$ to the Atlas V 551 increases the launch vehicle cost by approximately $\$ 20$ million (2001 dollars), ${ }^{32}$ but with REP power levels around $1.5 \mathrm{kWe}$, the performance of the REP-Chem configuration is comparable to SEPAerocapture and even attains shorter total trip times than the SEP-REPChem configuration launched on a Delta IV M+ (4,2).

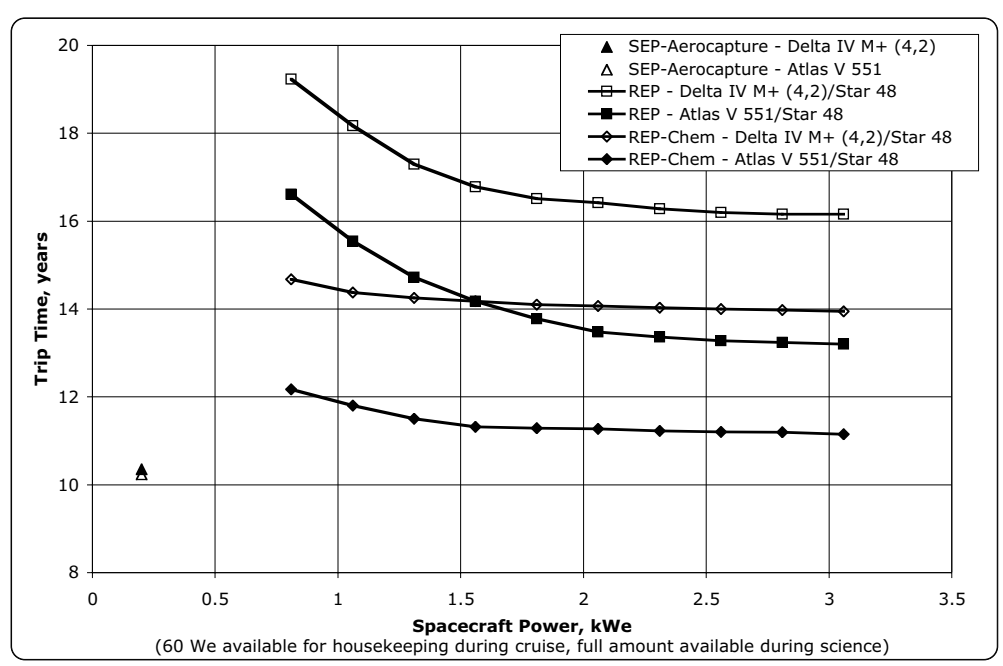

Figure 9: Spacecraft Performance on Different Launch Vehicles

\section{Conclusion}

Combinations of SEP, REP, and chemical propulsion systems, as well as aerocapture, were applied to a Neptune Orbiter mission. REP spacecraft power levels were varied to allow examination of the effect of REP power level on 
total mission trip time. When launched on a Delta IV M+ $(4,2)$, the SEP-Aerocapture configuration delivered the spacecraft to its final Neptune orbit in the least amount of time. The best-performing configurations with REP delivered the spacecraft to its final orbit with trip times 2-4 years longer than the SEP-Aerocapture configuration. Increasing the power level of the REP configurations did decrease total trip time with moderate power increases, but the benefit diminished with power levels over $1.5 \mathrm{kWe}$. The benefit of an increase in launch vehicle size, from a Delta IV M+ $(4,2)$ to an Atlas V 551, was also analyzed. The larger launch vehicle decreases the non-SEP configurations' trip times by approximately 3 years, independent of REP power level. The larger launch vehicle shortens the trip time of the REP-Chem configuration to within approximately 1 year of the SEP-Aerocapture configuration.

By no means was this study of the fidelity that is required for a flight program, but it does show the effects of the implementation of these technologies individually and in cooperation with each other. Only one mission was examined, but similar performance changes can be expected for similar outer solar system missions. Future work, if requested, can focus on adding more detail to the spacecraft designs. Currently, only the all-REP spacecraft and the SEP stage have been studied in sufficient depth to provide reliable mass estimates. As part of this study, assumptions were made to estimate the mass change in response to the configuration changes.

There appears to be promise in further investigation into the REP-Chem spacecraft. Not only does it deliver the spacecraft to Neptune with comparable trip times to the SEP-Aerocapture configuration, but it also provides a spacecraft with more power and a fully functional electric propulsion system. This REP system could also provide the capability to change orbits and complete the science investigations at Neptune and its moon Triton.

\section{References}

${ }^{1}$ Oleson, S.R., Gefert, L., Schreiber, J., McAdams, J., "Sub-Kilowatt Radioisotope Electric Propulsion for Outer Solar System Exploration", Forum on Innovative Approaches to Outer Planetary Exploration 2001-2020, Lunar and Planetary Institute, Houston, Texas, Feb, 2001.

${ }^{2}$ Oleson, S.R., Gefert, L., Patterson, M., Schreiber, J., Benson, S., McAdams, J., Ostdiek, P., "Outer Planet Exploration with Advanced Radioisotope Electric Propulsion”, IEPC-2001-0179, 27th International Electric Propulsion Conference, Pasadena, California, October, 2001.

${ }^{3}$ Noble, R.J., "Radioisotope Electric Propulsion of Small Payloads for Regular Access to Deep Space", AIAA 93-1897, 29th Joint Propulsion Conference, Monterey, California, 1993.

${ }^{4}$ Noble, R.J., "Radioisotope Electric Propulsion for Small Robotic Space Probes", British Interplanetary Society 49, 455-468, (1996).

${ }^{5}$ Noble, R. J., "Radioisotope Electric Propulsion of Sciencecraft to the Outer Solar System and Near-Interstellar Space", Nuclear News, Nov. 1999, pp 34-40.

${ }^{6}$ Oleson, S.R., Benson, S., Gefert, L., Patterson, M., Schreiber, J., "Radioisotope Electric Propulsion for Fast Outer Planetary Orbiters", AIAA-2002-3967, $38^{\text {th }}$ Joint Propulsion Conference, Indianapolis, Indiana, July, 2002.

${ }^{7}$ National Research Council, New Frontiers in the Solar System: An Integrated Exploration Strategy, National Academies Press, Washington, D.C., 2002, Chapter 7.

${ }^{8}$ Oleson, S., Gefert, L., Benson, S., Patterson, M., Noca, M., Sims, J., “Mission Advantages of NEXT: NASA's Evolutionary Xenon Thruster," AIAA Paper AIAA-2002-3969, 38 ${ }^{\text {th }}$ Joint Propulsion Conference, Indianapolis, IN, July 2002.

${ }^{9}$ Neptune Orbiter Mission Package, In-Space Integrated Space Transportation Activity by the IISTP Systems Analysis Team, April, 2001.

${ }^{10}$ Alagheband, A., Corazzini, T., Duchemin, O., Henny, D., Mason, R., Noca, M., "Neptune Explorer - An All Solar Powered Neptune Orbiter Mission," AIAA Paper AIAA-1996-2980, $32^{\text {nd }}$ Joint Propulsion Conference, Buena Vista, FL, July 1996.

11",The Vision for Space Exploration," National Aeronautics and Space Administration, February 2004.

${ }^{12}$ Schreiber, J. G., Thieme, L. G., "Overview of NASA GRC Stirling Technology Development," AIAA Paper AIAA-20036093, First International Energy Conversion Engineering Conference, Portsmouth, VA, August 2003.

${ }^{13}$ Pencil, E. J., Kamhawi, H., Arrington, L., “Overview of NASA's Pulsed Plasma Thruster Development Program,” AIAA Paper AIAA-2004-3455, 40 ${ }^{\text {th }}$ Joint Propulsion Conference, Fort Lauderdale, FL, July 2004.

${ }^{14}$ Oberto, R., Sweetser, T., et al., “Advanced Projects Design Team, Titan Orbiter 2003-10,” JPL Report ID \#658, 2003.

${ }^{15}$ Patterson, M., Domonkos, M., Foster, J., Haag, T., "NEXT: NASA's Evolutionary Xenon Thruster Development Status,” AIAA Paper AIAA-2003-4862, 39 th $^{\text {th }}$ Joint Propulsion Conference, Huntsville, AL, July 2003.

${ }^{16}$ Phelps, T. K., Wiseman, S., Komm, D. S., Bond, T., Pinero, L., "Development of the NEXT Power Processing Unit," AIAA Paper AIAA-2003-4867, 39 ${ }^{\text {th }}$ Joint Propulsion Conference, Huntsville, AL, July 2003.

${ }^{17}$ Aadland, R. S., Engelbrecht, C. S., Ganapathi, G. B., Browning, D. A., Wilson, F., Hoskins, W. A., "Xenon Propellant Management System for $40 \mathrm{~cm}$ NEXT Ion Thruster," AIAA Paper AIAA-2003-4880, $39^{\text {th }}$ Joint Propulsion Conference, Huntsville, AL, July 2003.

${ }^{18}$ Gershman, R., "Propulsion and Power Technology Needs of Future Solar System Exploration Missions," Solar System Exploration Theme Overview Presentation, March 1999. 
${ }^{19}$ TRW Space \& Technology Division, "Storable Thruster Upgrade Technology Program, Informal Report: Mission Analysis Task," Prepared for NASA GRC under contract NAS3-00176, September 2001.

${ }^{20}$ The Boeing Company, "Delta IV Payload Planner's Guide," MDC 00H0043, October 2000.

${ }^{21}$ The Boeing Company, “Delta IV Payload Planner's Guide Update - April 2002,” MDC 00H0043, April 2002.

${ }^{22}$ International Launch Systems (ILS), “Atlas Launch System Planner’s Guide,” Rev. 9, September 2001.

${ }^{23}$ Morton Thiokol, Inc., "Space Rocket Motors," June 1987.

${ }^{24}$ Fiehler, D. I., Oleson, S. R., "Mission Steering Profiles of Outer Planetary Orbiters Using Radioisotope Electric Propulsion," NASA TM-2004-212877, January 2004.

${ }^{25}$ Kluever, C. A., "Optimal Low-Thrust Interplanetary Trajectories by Direct Method Techniques," Journal of the Astronautical Sciences 45, 247-262 (1997).

${ }^{26}$ Betts, J. T., "Optimal Interplanetary Orbit Transfers by Direct Transcription," Journal of the Astronautical Sciences 42 , 247-268 (1994).

${ }^{27}$ Sauer, C., "A Users Guide to VARITOP: A General Purpose Low-Thrust Trajectory Optimization Program," Advanced Projects Group, Jet Propulsion Laboratory, November 1991.

${ }^{28}$ Patterson, M.J. and Grisnik, S.P., "Scaling of Ion Thrusters to Low Power," IEPC-97-098, $25^{\text {th }}$ International Electric Propulsion Conference, Cleveland, Ohio, August 1997 Also NASA TM-1998-206530.

${ }^{29}$ Patterson, M.J., "Low-Power Ion Thruster Development Status," AIAA Paper No. 98-3347, 34 ${ }^{\text {th }}$ Joint Propulsion Conference, Cleveland, Ohio, July 1998.

${ }^{30}$ Foster, J.E. and Patterson, M.J, "Enhanced Discharge Performance in a Ring Cusp Plasma Source," IEPC 99-159, 26 ${ }^{\text {th }}$ International Electric Propulsion Conference, Kitakyushu, Japan, October 1999, Also NASA TM-2000-209765.

${ }^{31}$ Menart, J.A. and Patterson, M.J., "Magnetic Circuit for Enhanced Discharge Chamber Performance of a Small Ion Thruster," AIAA Paper No. 98-3343, 34 ${ }^{\text {th }}$ Joint Propulsion Conference, Cleveland, Ohio, July 1998.

${ }^{32}$ Isakowitz, S. J., Hopkins, J., Hopkins Jr., J. P., International Reference Guide to Space Launch Systems, $3^{\text {rd }}$ ed., AIAA General Publication Series, AIAA, New York, 1999, pp. 55, 97. 
Public reporting burden for this collection of information is estimated to average 1 hour per response, including the time for reviewing instructions, searching existing data sources, gathering and maintaining the data needed, and completing and reviewing the collection of information. Send comments regarding this burden estimate or any other aspect of this collection of information, including suggestions for reducing this burden, to Washington Headquarters Services, Directorate for Information Operations and Reports, 1215 Jefferson Davis Highway, Suite 1204, Arlington, VA 22202-4302, and to the Office of Management and Budget, Paperwork Reduction Project (0704-0188), Washington, DC 20503.

\begin{tabular}{|l|l|l|}
\hline 1. AGENCY USE ONLY (Leave blank) & $\begin{array}{c}\text { 2. REPORT DATE } \\
\text { August } 2004\end{array}$ & $\begin{array}{r}\text { 3. REPORT TYPE AND DATES COVERED } \\
\text { Technical Memorandum }\end{array}$ \\
\hline
\end{tabular}

\section{TITLE AND SUBTITLE} 5. FUNDING NUMBERS

Neptune Orbiters Utilizing Solar and Radioisotope Electric Propulsion

6. AUTHOR(S)

Douglas I. Fiehler and Steven R. Oleson

WBS-22-973-80-60

\section{PERFORMING ORGANIZATION NAME(S) AND ADDRESS(ES)}

National Aeronautics and Space Administration

John H. Glenn Research Center at Lewis Field

Cleveland, Ohio 44135-3191

8. PERFORMING ORGANIZATION REPORT NUMBER

\section{E-14727}

\section{SPONSORING/MONITORING AGENCY NAME(S) AND ADDRESS(ES)}

National Aeronautics and Space Administration

Washington, DC 20546-0001

10. SPONSORING/MONITORING AGENCY REPORT NUMBER

NASA TM-2004-213220

AIAA-2004-3978

\section{SUPPLEMENTARY NOTES}

Prepared for the 40th Joint Propulsion Conference and Exhibit cosponsored by the AIAA, ASME, SAE, and ASEE, Fort Lauderdale, Florida, July 11-14, 2004. Douglas I. Fiehler, QSS Group, Inc., 21000 Brookpark Road, Cleveland, Ohio 44135; and Steven R. Oleson, NASA Glenn Research Center. Responsible person, Douglas I. Fiehler, organization code 5430, 216-433-2584.

Unclassified - Unlimited

Subject Category: 20

Distribution: Nonstandard

Available electronically at http://gltrs.grc.nasa.gov

This publication is available from the NASA Center for AeroSpace Information, 301-621-0390.

\section{ABSTRACT (Maximum 200 words)}

In certain cases, Radioisotope Electric Propulsion (REP), used in conjunction with other propulsion systems, could be used to reduce the trip times for outer planetary orbiter spacecraft. It also has the potential to improve the maneuverability and power capabilities of the spacecraft when the target body is reached as compared with non-electric propulsion spacecraft. Current missions under study baseline aerocapture systems to capture into a science orbit after a Solar Electric Propulsion (SEP) stage is jettisoned. Other options under study would use all REP transfers with small payloads. Compared to the SEP stage/Aerocapture scenario, adding REP to the science spacecraft as well as a chemical capture system can replace the aerocapture system but with a trip time penalty. Eliminating both the SEP stage and the aerocapture system and utilizing a slightly larger launch vehicle, Star 48 upper stage, and a combined REP/Chemical capture system, the trip time can nearly be matched while providing over a kilowatt of science power reused from the REP maneuver. A Neptune Orbiter mission is examined utilizing single propulsion systems and combinations of SEP, REP, and chemical systems to compare concepts.

\footnotetext{
14. SUBJECT TERMS Electric propulsion

\begin{tabular}{|c|c|}
\hline $\begin{array}{c}\text { 17. SECURITY CLASSIFICATION } \\
\text { OF REPORT } \\
\text { Unclassified }\end{array}$ & $\begin{array}{c}\text { 18. SECURITY CLASSIFICATION } \\
\text { OF THIS PAGE } \\
\text { Unclassified }\end{array}$ \\
\hline
\end{tabular}
}

Space missions; Systems analysis; Trajectories; Solar electric propulsion; Trajectory optimization; Ion propulsion;

Spacecraft orbits; Propulsion system configurations; Propulsion system performance; Space exploration;

Spacecraft configurations; Ion engines; Chemical propulsion; Propulsion; Aerocapture; Launch vehicles;

NSN 7540-01-280-5500

\begin{tabular}{|l|} 
15. NUMBER OF PAGES \\
15 \\
\hline 16. PRICE CODE \\
\hline 20. LIMITATION OF ABSTRACT \\
\hline
\end{tabular}

Standard Form 298 (Rev. 2-89)

Prescribed by ANSI Std. Z39-18 298-102 

